\title{
Association of Hypertension with Long-Term Overweight Status and Weight Gain: the CroHort Study
}

\author{
Ana Ivičević Uhernik ${ }^{1}$ Marijan Erceg ${ }^{1}$ and Sanja Musić Milanovićé,2 \\ ${ }^{1}$ Croatian National Institute of Public Health, Zagreb, Croatia \\ 2 University of Zagreb, School of Medicine, Andrija Štampar School of Public Health, Zagreb, Croatia
}

\begin{abstract}
A B S T R A C T
Overweight is associated with hypertension, but longitudinal studies on the effect of weight gain on blood pressure are relatively rare. Aim of this study was to investigate association of long-term overweight status as well as of becoming overweight with hypertension. Odds of hypertension in 2008 were calculated for 1,383 respondents from Croatian Adult Health Cohort Study (CroHort) who had normal blood pressure in 2003. The results showed that for women both long-term overweight status and recently becoming overweight (in the last 5 years) were significantly associated with development of hypertension, while for men this was true only for long-term overweight. Prevention activities aimed at maintenance of normal body weight should be important part of primary prevention of hypertension.
\end{abstract}

Key words: hypertension, overweight, weight gain, CroHort study

\section{Introduction}

Hypertension is important risk factor for circulatory diseases and related to increase in mortality and cardiovascular morbidity ${ }^{1-4}$. Overweight is directly associated with hypertension - risk of being hypertensive is two to six times higher in overweight individuals ${ }^{5-7}$. Strength of that association varies due to differences in age, gender, ethnicity and lifestyle ${ }^{8-11}$. Intervention studies showed that weight loss can prevent emergence of hypertension $^{12,13}$ and reduce increased blood pressure in obese individuals ${ }^{14}$ and lower blood pressure is associated with reduced incidence of stroke and myocardial infarction ${ }^{15}$. The prevalence of both hypertension and overweight is increasing worldwide ${ }^{16-18}$ as well as in Croatia ${ }^{19}$ and they both are significant public health problems.

The exact mechanism whereby excessive weight causes increase in blood pressure is still unknown, however, one of its elements is stimulation of sympathetic activation by weight gain and influence on insulin and leptin levels ${ }^{20}$. Activation of renin-angiotensin system and physical compression of the kidney by fat tissue might also be involved in that process ${ }^{21}$.
Results of longitudinal studies on the effect of weight gain on blood pressure confirmed that weight gain increases risk of hypertension independently of baseline weight status, although there are differences in strength of that association depending on age and gender of respondents ${ }^{22-24}$.

In this study we investigated association of long-term overweight status as well as of becoming overweight with hypertension in Croatian Adult Health Cohort Study (CroHort) - a follow-up study of the original cross-sectional research.

\section{Sample and Methods}

\section{Sample}

The sample of this study consisted of 3,229 respondents (1,015 male and 2,214 female) who participated in both Croatian Adult Health Survey 2003 and the follow-up Croatian Adult Health Cohort Study (CroHort) in 2008. They were 18 years or older at the time of the first 
survey. Further details on this sample were described elsewhere ${ }^{25}$.

Public health nurses measured blood pressure in respondents' homes both in 2003 and 2008, while weight and height were self-reported by respondents on both occasions and recorded on a questionnaire by public health nurses. On both occasions blood pressure was measured twice using a mercury sphygmomanometer, with respondents seated for 20 minutes between the measurements.

Only respondents with normal blood pressure in 2003 (systolic blood pressure $<140 \mathrm{mmHg}$, diastolic blood pressure $<90 \mathrm{mmHg}$ and no record on usage of hypertension medications) were analysed encompassing 1,383 respondents (396 male and 987 female).

\section{Variables}

Respondents who stated that they use anti-hypertensive drugs or whose average blood pressure calculated from two measurements was equal or higher than $140 \mathrm{mmHg}$ for systolic or equal or higher than 90 $\mathrm{mmHg}$ for diastolic blood pressure, were categorized as hypertensive.

Respondents whose BMI was $25 \mathrm{~kg} / \mathrm{m}^{2}$ or higher were classified as overweight.

\section{Statistical analysis}

Prevalence of respondents who had normal BMI both in 2003 and 2008, who were overweight both in 2003 and 2008 and who had normal BMI 2003, but were overweight in 2008 was calculated for each gender as well as prevalence of hypertensive and normotensive respondents in 2008.

Prevalence of hypertension in 2008 was calculated for respondents with normal BMI both in 2003 and 2008, for respondents who were overweight both in 2003 and 2008 and for respondents who had normal BMI in 2003, but were overweight in 2008, separately for men and women. The logistic regression analysis (adjusted for age) was used to calculate OR for hypertension in 2008 for respondents who were overweight both in 2003 and 2008 (BMI $\geq 25$ ) and for respondents who had normal BMI in 2003 (BMI < 25), but were overweight in 2008 (BMI $\geq 25$ ) compared to those respondents who maintained normal BMI $(\mathrm{BMI}<25)$ both in 2003 and 2008.
All confidence intervals (CI) were calculated with $95 \%$ probability levels.

Statistical analysis was performed using SPSS (version 14.01; License: Croatian National Institute of Public Health).

\section{Results}

Both among men and women there was significantly higher percentage of respondents who were overweight both in 2003 and 2008 than respondents with normal BMI both in 2003 and 2008. No significant difference was recorded between men and women in percentage of respondents with normal BMI both in 2003 and 2008, but percentage of respondents overweight both in 2003 and 2008 was higher among men, while percentage of respondents with normal BMI in 2003, but overweight in 2008, was significantly higher among women.

There was no significant difference among genders in percentage of respondents who were hypertensive in 2008 (Table 1).

For men, percentages of respondents with hypertension among respondents who had normal BMI in 2003 and 2008, respondents who were overweight both in 2003 and 2008 and respondents who had normal BMI in 2003, but were overweight in 2008 were not significantly different. For women, percentage of respondents with hypertension among respondents who had normal BMI in 2003 and 2008 was significantly lower than among respondents who were overweight both in 2003 and 2008 and respondents who had normal BMI in 2003, but were overweight in 2008.

For men, logistic regression analysis showed that being overweight both in 2003 and 2008 was associated with OR 1.70 for hypertension in 2008 compared to men that maintained normal weight both in 2003 and 2008. Having normal weight in 2003 and being overweight in 2008 was not associated with increased OR for hypertension among men. For women, logistic regression analysis showed that being overweight both in 2003 and 2008 was associated with OR 3.39 for hypertension in 2008, while having normal weight in 2003 and being overweight in 2008 was associated with OR 3.79 for hypertension in 2008 compared to women that maintained normal weight both in 2003 and 2008 (Table 2).

TABLE 1

CHARACTERISTICS OF THE STUDY PARTICIPANTS WHO WERE NORMOTENSIVE IN 2003

\begin{tabular}{lcccccc}
\hline \multirow{2}{*}{ Characteristic } & \multicolumn{3}{c}{ Men } & \multicolumn{3}{c}{ Women } \\
\cline { 2 - 7 } & Number & $\%$ & $95 \%$ CI & Number & $\%$ & $95 \%$ CI \\
\hline normal BMI in 2003 and 2008 & 109 & 27.5 & $23.1-31.9$ & 325 & 32.9 & $30.0-35.9$ \\
overweight in 2003 and 2008 & 200 & 50.5 & $45.6-55.4$ & 409 & 41.4 & $38.4-44.5$ \\
normal BMI in 2003, but overweight in 2008 & 50 & 12.6 & $9.4-15.9$ & 200 & 20.3 & $17.8-22.8$ \\
hypertensive in 2008 & 146 & 36.9 & $32.1-41.6$ & 326 & 33.0 & $30.1-36.0$ \\
normotensive in 2008 & 250 & 63.1 & $58.4-67.9$ & 661 & 67.0 & $64.0-69.9$ \\
\hline
\end{tabular}


TABLE 2

ASSOCIATION OF OVERWEIGHT AND WEIGHT GAIN WITH HYPERTENSION IN 2008

\begin{tabular}{|c|c|c|c|c|}
\hline Characteristic & $\%$ of hypertensive & $95 \% \mathrm{CI}$ & $\mathrm{OR}^{*}$ & $95 \% \mathrm{CI}$ \\
\hline \multicolumn{5}{|l|}{ Men } \\
\hline normal BMI in 2003 and 2008 & $30.3 \%$ & $21.6-38.9$ & 1.00 & \\
\hline overweight in 2003 and 2008 & $44.5 \%$ & $37.6-51.4$ & 1.70 & $1.02-2.82$ \\
\hline normal BMI in 2003, but overweight in 2008 & $26.0 \%$ & $13.8-38.2$ & 0.96 & $0.44-2.09$ \\
\hline \multicolumn{5}{|l|}{ Women } \\
\hline normal BMI in 2003 and 2008 & $15.1 \%$ & $11.2-19.0$ & 1.00 & \\
\hline overweight in 2003 and 2008 & $43.0 \%$ & $38.2-47.8$ & 3.39 & $2.33-4.93$ \\
\hline normal BMI in 2003, but overweight in 2008 & $37.5 \%$ & $30.8-44.2$ & 3.79 & $2.45-5.87$ \\
\hline
\end{tabular}

* adjusted for age

\section{Discussion}

For women, both long-term overweight status and becoming overweight were significantly associated with development of hypertension, while for men this was true only for long-term overweight. Even recently becoming overweight (in last 5 years or even shorter period) can increase risk for hypertension among women. This is in accordance with results of various previous studies which reported a positive association between change in BMI and change in blood pressure ${ }^{22-24}$. However, there are some differences: in majority of the studies change in weight was more intensively associated with blood pressure increase than stabile overweight status $^{23,24,26}$, while this was not the case in this study. Stronger association between increase in body weight and hypertension among women compared to men is in accordance with results of some studies ${ }^{22}$, but there are also studies with opposite results ${ }^{24}$ which emphasize the need for further research of gender differences in influence of weight increase on hypertension.

This study also confirmed association between long-term overweight status and hypertension among both genders which is in accordance with previous research ${ }^{13}$.

Certain limitations of this study should be taken into account in interpretation of its results: respondents were characterized as hypertensive on the basis of average from only two blood pressure measurements made in relatively short time span or on the basis of respondent's statement about usage of antihypertensive treatment

\section{R E F E R E N C E S}

1. KANNEL WB, JAMA, 275 (1996) 1571. — 2. ROSENGREN A, WELIN L, TSIPOGIANNI A, WILHELMSEN L, BMJ, 299 (1989) 1127. — 3. KANNEL WB, Am Heart J, 114 (1987) 918. - 4. MACMAHON S, PETO R, CUTLER J, COLLINS R, SORLIE P, NEATON J, ABBOTT R, GODWIN J, DYER A, STAMLER J, Lancet, 82 (1990) 7. - 5. JOUSILAHTI P TUOMILEHTO J, VARTIAINEN E, VALLE T, NISSINEN A, J Hum Hypertens, 9 (1995) 847. — 6. DICKEY RA, JANICK JJ, Endocr Pract, 7 (2001) 392. - 7. MISHRA V, ARNOLD F, SEMENOV G, HONG R, MUKURIA A, Eur J Clin Nutr, 60 (2006) 1355. - 8. IVICEVIC UHERNIK A ERCEG M, MUSIĆ MILANOVIĆ S, Public Health Nutr, 12 (2009) 97. 9. DYER AR, ELLIOTT P, SHIPLEY M, Am J Epidemiol, 131 (1990) 589. which was potentially prone to response and recall bias. Self-reporting of height and weight might have also been influenced by response bias. As blood pressure measurements were made during public health nurse's visit to respondent's home, the incidence of "white coat hypertension« might have been reduced.

Extent of overweight among the respondents, high incidence of becoming overweight in five years period and strong association of overweight with hypertension point out the importance of activities aimed at maintenance of normal body weight as a part of primary prevention of hypertension. According to the current guidelines, blood pressure measurement is recommended once every two years for healthy adults if they have blood pressure below $120 / 80 \mathrm{mmHg}$ and once per year if they have blood pressure in prehypertension range $120-139 / 80-89 \mathrm{mmHg}^{27}$. Women who have recently become overweight as well as both men and women who have been long-term overweight and their health care providers should pay special attention to measuring their blood pressure regularly in order to promptly detect emergence of hypertension and start treatment as soon as possible.

\section{Acknowledgements}

This article was prepared as a part of scientific project "Regionalism of cardiovascular behavioural risk factors model of intervention « (108-1080135-0264) supported by Ministry of Science, Education and Sport of the Republic of Croatia.

- 10. BABA S, PAN WH, UESHIMA H, OZAWA H, KOMACHI Y, STAMLER R, RUTH K, STAMLER J, J Hum Hypertens, 5 (1991) 317. 11. HE J, KLAG MJ, WHELTON PK, CHEN JY, QIAN MC, HE GQ, Am J Epidemiol, 139 (1994) 380. - 12. HE J, WHELTON PK, APPEL LJ, CHARLESTON J, KLAG MJ, Hypertension, 35 (2000) 544. — 13. STEVENS VJ, OBARZANEK E, COOK NR, LEE IM, APPEL LJ, SMITH WEST D, MILAS NC, MATTFELDT-BEMAN M, BELDEN L, BRAGG C MILLSTONE M, RACZYNSKI J, BREWER A, SINGH B, COHEN J, Ann Intern Med, 134 (2001) 1. - 14. JONES DW, Am J Hypertens, 9 (1996) 50s. - 15. COLLINS R, Lancet, 335 (1990) 827. - 16. KEARNEY PM WHELTON M, REYNOLDS K, WHELTON PK, HE J, J Hypertens, 22 
(2004) 11. - 17. KEARNEY PM, WHELTON M, REYNOLDS K, MUNTNER P, WHELTON PK, HE J, Lancet, 365 (2005) 217. — 18. KELLY T, YANG W, CHEN CS, REYNOLDS K, HE J, Int J Obes (Lond), 32 (2008) 1431. - 19. ERCEG M, KERN J, BABIĆ-ERCEG A, IVIČEVIĆ UHER NIK A, VULETIĆ S, Coll Antropol, 33 (Suppl 1) (2009) 19. — 20. MASUO K, MIKAMI H, OGIHARA T, TUCK ML, Hypertension, 35 (2000) 1135. - 21. HALL JE, BRANDS MW, HILDEBRANDT DA, KUO J, FITZGERALD S, Braz J Med Biol Res, 33 (2000) 605 - 22. WILSGAARD T, SCHIRMER H, ARNESEN E, Arch Intern Med, 160 (2000) 2847. - 23 DROYVOLD WB, MIDTHJELL K, NILSEN TI, HOLMEN J, Int J Obes
(Lond), 29 (2005) 650 - 24 CHEN PC, SUNG FC, SU TC, CHIEN KL, HSU HC, LEE YT, J Hypertens, 27 (2009) 1370. — 25. IVIČEVIĆ-UHERNIK A, VULETIĆ S, KERN J, DEČKOVIĆ-VUKRES V, MIHEL S, ERCEG M, PRISTAŠA I, Coll Antropol, 36 (Suppl 1) (2012) 3. — 26. BOT M, SPIJKERMAN AM, TWISK JW, VERSCHUREN WM, Eur J Epidemiol, (2010) 125. - 27. NATIONAL HEART, LUNG AND BLOOD INSTITUTE, The Seventh Report of the Joint National Comitee on Prevention, Detection, Evaluation, and Treatment of High Blood Pressure (National Heart, Lung and Blood Institute, Bethesda, 2004).

\section{A. Ivičević Uhernik}

Croatian National Institute of Public Health, Rockefellerova 7, 10000 Zagreb, Croatia

e-mail: ana.ivicevic@hzjz.hr

\section{POVEZANOST HIPERTENZIJE S DUGOTRAJNOM PREKOMJERNOM TEŽINOM I DOBIVANJEM NA TEŽINI: CroHort STUDIJA}

\section{S A Ž E T A K}

Povećana težina povezana je s hipertenzijom, međutim longitudinalne studije o utjecaju dobivanja na težini na krvni tlak relativno su rijetke. Cilj ove studije bio je istražiti povezanost dugotrajne prekomjerne težine, kao i prekomjernog dobivanja tjelesne težine s hipertenzijom. Za 1,383 ispitanika Hrvatske kohortne studije kardiovaskularnog zdravlja koji su imali normalni krvni tlak 2003. godine, izračunat je rizik za hipertenziju u 2008. godini. Rezultati su pokazali da su kod žena i dugotrajna prekomjerna težina, kao i nedavno (tijekom posljednjih 5 godina) prekomjerno dobivanje tjelesne težine, značajno povezani s pojavom hipertenzije, dok je kod muškaraca povezanost s hipertenzijom zabilježena samo za dugotrajnu prekomjernu težinu. Preventivne aktivnosti usmjerene na održavanje normalne tjelesne težine trebale bi biti važan dio primarne prevencije hipertenzije. 